\title{
Ayurvedic Management of Alcohol Withdrawal Syndrome - A Case Report
}

\section{Jiljith $\mathrm{A}^{1}$ and Jithesh $\mathrm{M}^{2 *}$}

${ }^{1}$ Department of Manovijnan, VPSV Ayurveda College, India

${ }^{2}$ Department of Kayachikitsa and Post Graduate Studies in Manovijnan, VPSV Ayurveda College, India

*Corresponding author: Jithesh Madhavan, HOD and Associate Professor,

\section{Case Report}

Volume 2 Issue 6

Received Date: September 17, 2018

Published Date: November 05, 2018

DOI: $10.23880 / \mathrm{mjccs}-16000184$ Department of Kayachikitsa and Post Graduate Studies in Manovijnan, VPSV Ayurveda College, Kottakkal, Kerala, India, Tel: 9447882885; Email: drjitheshm@gmail.com

\section{Abstract}

Alcohol abuse is not only having impact on individual and families, but creates a lasting social burden on the community and even national level. When a chronic alcoholic tries to reduce or completely impede the alcohol intake, then a cluster of symptoms manifests which is called as alcohol withdrawal syndrome (AWS). The symptoms include nausea, vomiting, sweating, headache, auditory, visual and tactile hallucinations, delirium tremens etc. There is need of management from the primary stage itself. The chronic use of alcohol leads to a metabolic error termed as 'Ama' condition and Agnimandya with in the Koshta and eventually leads to obstruction of srotus. Madya also results in depletion of Ojus due to the opposite qualities in it, against the properties of Ojus and decreased food intake resulting in Vatha and Kapha aggravation. So initial treatment designed should be aimed of Vata Kaphahara and Srotosodhana. Along with the same, Ayurvedic drugs and Pancakarma procedures can be selected to deal the AWS. Here we are discussing the case of a 48 year old male patient presented with AWS and treated in our hospital with Pancakarma procedures and selected Ayurvedic drugs with the selected protocol The condition was assessed before and after the treatment with Clinical Institute Withdrawal Assessment of Alcohol revised scale (CIWA-Ar scale).

Key words: Alcohol withdrawal syndrome; Agnimandya; Ojakshaya; Pancakarma; CIWA-Ar scale 


\section{Medical Journal of Clinical Trials \& Case Studies}

\section{Introduction}

Alcoholic beverages were an integral part of our ethnic cultures, religious ceremonies, celebrations etc. It is a transparent, colorless, mobile and volatile liquid, having a characteristics spirituous odour and a burning taste [1-5]. It has got tonic and poisonous effects depends on the amount of intake. On moderate use of alcohol it causes a feeling of livelier, easier and relaxed [6]. When a person consumes alcohol regularly, despite of the fact that it causes consequences in their life, it is termed as Alcohol abuse [7]. Alcohol dependency is a full-blown addiction to alcohol [8].

In DSM V, alcohol abuse and alcohol dependence integrated into single entity, ie. Alcohol Use Disorders [9]. The etiological factors of alcohol dependency are epigenetic, psychological, social, biological and environmental factors, along with genetic susceptibility, is paving increased susceptibility, to all sorts of alcoholism [10]. The basic cause of alcoholism is resulting from the maladaptive coping response due to lowered self-esteem, so as to face high risk situation [11].

The drug which takes away the discriminative power of an individual by the virtue of the enhancement in the property of "tamas" is called 'madakari' drug, in the ancient science [12]. If a person is administering 'Madya' by taking into account the desa, kala and matra and even kula or familial status, then it will acts in is a positive manner [13]. Madya possess various properties and actions such as brihmaṇa, balya, rocana, dippana, hridya etc. It is effective in the management of dyssomnias. In reduced sleep, it improves the quality of nidra in fact by its action on providing clarity to the channels of the mind. It also provides bala as well [14].

Madya is explained to have qualities or gunas similar to visha, but in a milder form and also opposite to qualities of ojas. The alteration of ojus results in the imbalance between the dhatus and also in immune-compromise in the individual. So, if it is not administered properly, results in harm to the body and is termed as slow poison, by many. In Ayurveda, several recipes for preparation of madya, its indication and use are explained in detail. The condition resulting from the unfavorable intake of madya is explained under the broad heading of 'Madatyaya'. Madatyaya is of four types as per the distribution of dosha status involved in the pathogenesis as Vataja, Pittaja, Kaphaja and Sannipata [15]. The symptomatology as well as management protocol is explained in detail [16].
In Madatyaya, all the three doshas may be involved, but the permutation may vary as per the causative factors [17]. So, management should be aimed primarily at pacifying the most predominant dosha. The ama stage if identified may be managed initially and get rid of. If all the doshas are aggravated equally then, Kapha should be pacified first, followed by Pitta and Vata respectively. The chronic conditions are usually of Pitta and Vata aggravation and needs its management [18]. Even the judicious use of preparation of medicated madya eg. Sreekhandasava, is also mentioned in certain stages.

Acarya Vagbhata explains the madatyaya treatment to be performed up to 7 or 8 days so as to overcome the ill effects, which is quite correct in the case of AWS [19]. It has been explained that the symptoms due to localization of madya in improper channels will be exhibiting only for 7 or 8 days and treatment is needed for those days [19]. Mild to moderate symptoms on stoppage of consumption of alcohol subsides by 7 or 8 days, with treatment from our experience. But in the case of Alcohol dependence, one has to adopt sodhana procedures followed by appropriate rasayana such as medhya rasayana, so as to attain enhancement [20].

Alcohol withdrawal syndrome (AWS) occurs when a heavy drinker suddenly stops or significantly reduces their alcohol intake [21]. AWS consists of symptoms and signs arising in alcohol- dependent individuals, typically within 24 - 48 hours of consumption of their last drink. AWS occurs intentionally in those seeking abstinence, but in an alcohol dependent patient it may occurs quite unexpectedly, even after admission to hospital and is very common.

Nausea and vomiting, tremor, paroxysmal sweats, anxiety, agitation, tactile disturbances, auditory disturbances, visual disturbances, head ache and fullness in head and orientation and clouding of sensorium are the major symptoms of AWS. But in case of abrupt cessation of alcohol consumption by a patient with alcohol dependence, may cause delirium tremens and withdrawal seizures, which may even leads to death [22]. Alcohol symptoms are occurring because of enhanced $\mathrm{N}$ - methyl D - asperate (NMDA) receptor function; reduced transmission and deregulation of the dopaminergic system etc. [23]. Intervention, detoxification and rehabilitation are the three steps of management available [24]. 


\section{Medical Journal of Clinical Trials \& Case Studies}

\begin{tabular}{|c|l|}
\hline Criteria & \multicolumn{1}{c|}{ Symptoms } \\
\hline Criteria A & Cessation of (or reduction in) alcohol use that has been heavy and prolonged \\
\hline \multirow{2}{*}{ Criteria B } & $\begin{array}{l}\text { Two (or more) of the following, developing within several hours to a few days after the cessation of } \\
\text { (or reduction in) alcohol use described in Criterion A }\end{array}$ \\
\cline { 2 - 3 } & $\begin{array}{l}\text { 1. Autonomic hyperactivity (e.g., sweating or pulse rate greater than 100 bpm). 2. Increased hand } \\
\text { tremor. 3. Insomnia. 4. Nausea or vomiting. 5. Transient visual, tactile, or auditory hallucinations or } \\
\text { illusions. 6. Psychomotor agitation. 7. Anxiety. 8. Generalized tonic-clonic seizures. }\end{array}$ \\
\hline \multirow{2}{*}{ Criteria C } & $\begin{array}{l}\text { The signs or symptoms in criterion B cause clinically significant distress or impairment in social, } \\
\text { occupational, or other important areas of functioning }\end{array}$ \\
\hline \multirow{2}{*}{ Criteria D } & $\begin{array}{l}\text { The signs or symptoms are not attributable to another medical condition and are not better } \\
\text { explained by another mental disorder, including intoxication or withdrawal from another substance. }\end{array}$ \\
\cline { 2 - 3 } & $\begin{array}{l}\text { Specify if: With perceptual disturbances: This specifier applies in the rare instance when } \\
\text { hallucinations (usually visual or tactile) occur with intact reality testing, or auditory, visual, or tactile } \\
\text { illusions occur in the absence of a delirium [26] }\end{array}$ \\
\hline
\end{tabular}

Table 1: Diagnostic Criteria [25].

\section{Clinical Presentation}

A 48 years old Indian Muslim male patient hailing from Kottakkal, presented in Ayurvedic psychiatry OPD, with the complaints of tremulousness of hands, increased agitation and anxiety, nausea and vomiting, increased sweating and decreased sleep. He had got married at the age of 20. At the age of 25, he started the intake of alcohol due to peer group pressure. Initially there was only occasional use, but later it developed into frequent use of alcohol. On increased worries, he amplified the amount of alcohol intake. This caused familial conflicts and he got divorced due to this alcohol problem. He got married again to a younger lady, she has some psychological problems. Due to the familial issues, the intake of alcohol increased. Daily intake of alcohol was there, since last 2 years. By the time, he lost his job and financial crisis got worsened. He thought about to stop the alcohol, but he couldn't stop by himself. So he was admitted in the IPD of our institution.

\section{Clinical Observations}

Patient presented with symptoms such as tremulousness of hands, increased agitation and anxiety, nausea and vomiting, increased sweating and decreased sleep. On examination the patient was found to be so anxious, the appetite was much reduced. He was of medium body built, avara in satwa, avara in rogi bala and of avara in abhyavaharanashakti and Jaranashakti (low food intake and digestive power). The case was diagnosed as AWS with the above mentioned diagnostic criteria [27].

\begin{tabular}{|c|c|}
\hline Dosha & Vata + Pitta+Kapha+ \\
\hline Dooshya & Rasa, Rakta \\
\hline Agni & Manda \\
\hline Koshta & Madhyama \\
\hline \multirow{2}{*}{ Prakruthi } & Saareerika prakruthi - Vata, Pitta \\
\cline { 2 - 2 } & Manasika prakruthi - Rajas, Thamas \\
\hline
\end{tabular}

Table 2: Assessment of Ayurvedic Parameters.

On examination, the srotas involved was mainly the rasavaha, raktavaha and samjavaha srotuses based on their respective symptoms. On Mental Status Examination, attention and concentration were partially impaired. Baseline hematological investigations, Renal Function Test and Liver Function Tests were done, which revealed that Haemoglobin: 15.9gm\%, ESR: 20/hr, Total Count: 6700cells $/ \mathrm{mm}^{3}$, Fasting Blood Sugar: $78 \mathrm{mg} / \mathrm{dl}$, Total Cholesterol: $205 \mathrm{mg} / \mathrm{dl}$, Serum Creatinine: 0.4, SGOT - 92U/L, SGPT: $61 \mathrm{U} / \mathrm{L}$, Total bilirubin: $1.02 \mathrm{mg} / \mathrm{dl}$, direct bilirubin: $0.39 \mathrm{mg} / \mathrm{dl}$. 


\section{Medical Journal of Clinical Trials \& Case Studies}

\section{Management Protocol}

\begin{tabular}{|c|c|c|c|c|}
\hline Treatment & Days & Medicine & Rationale & Remarks \\
\hline Ajamoda arka & 7 days & $\begin{array}{c}20 \mathrm{ml} \text { Ajamodaarka }+10 \mathrm{~m} \\
\text { water }\end{array}$ & $\begin{array}{c}\text { Vata kaphahara } \\
\text { Ama pachana } \\
\text { Agnideepthi } \\
\text { Vata anulomana } \\
\text { Hrudya and Rasa preenana }\end{array}$ & $\begin{array}{c}\text { Sleep improved } \\
\text { Appetite increased }\end{array}$ \\
\hline Snehapana & 7 days & $\begin{array}{l}\text { Kalyanaka ghritam (30 - } \\
300 \mathrm{ml})\end{array}$ & $\begin{array}{c}\text { Vata pitta samana } \\
\text { Brimhana } \\
\text { Medhya }\end{array}$ & $\begin{array}{l}\text { Samyak laksana attained on } 7 \text { th } \\
\text { day (Bowel regular, Presence of } \\
\text { sneha in stool, Fatigue, aruci, } \\
\text { nausea, Aversion towards ghee) }\end{array}$ \\
\hline $\begin{array}{l}\text { Abhyanga and } \\
\text { Ushmasweda }\end{array}$ & 3 days & Dhanwanthara taila & $\begin{array}{c}\text { For attaining vilayana or } \\
\text { draveekarana of dhatugata dosas }\end{array}$ & Comfortable \\
\hline Virechana & 1 day & $\begin{array}{l}\text { Avipathi churna - } 30 \mathrm{gm} \\
\text { with warm water, } 8 \mathrm{AM}\end{array}$ & $\begin{array}{l}\text { Koshta shodhana } \\
\text { Pittasamana }\end{array}$ & $\begin{array}{c}\text { Sleep disturbed } \\
\text { Lightness to Koshta }\end{array}$ \\
\hline
\end{tabular}

Table 3: Treatment procedures.

\begin{tabular}{|c|c|c|c|c|}
\hline No. & Medicines & Dose & Time & Rationale \\
\hline 1 & Drakshadi kashayam & $90 \mathrm{ml}$ & $8 \mathrm{am}, 8 \mathrm{pm}$ & $\begin{array}{c}\text { Vatapittasamana } \\
\text { To reduce the fatique }\end{array}$ \\
\hline 2 & Cheriya Chandanadi Tailam & Head & $\begin{array}{c}\text { For sleep } \\
\text { Vatha Pittahara }\end{array}$ \\
\hline 3 & $\begin{array}{c}\text { Sweta Sankhupushpi churnam } 3 \mathrm{gm}+ \\
\text { Yashti churnam - } 1 \mathrm{gm}\end{array}$ & $4 \mathrm{gm}$ & $\begin{array}{c}\text { Calmness of mind } \\
\text { Enhances sleep } \\
\text { Medhya rasayana }\end{array}$ \\
\hline
\end{tabular}

Table 4: Internal medicines.

\section{Assessment}

Assessment of effect of the therapy was done on the basis of changes observed at the clinical level. Numerical score was assigned for each of the signs and symptoms by using Clinical Institute Withdrawal Assessment of Alcohol revised scale (CIWA-Ar scale).

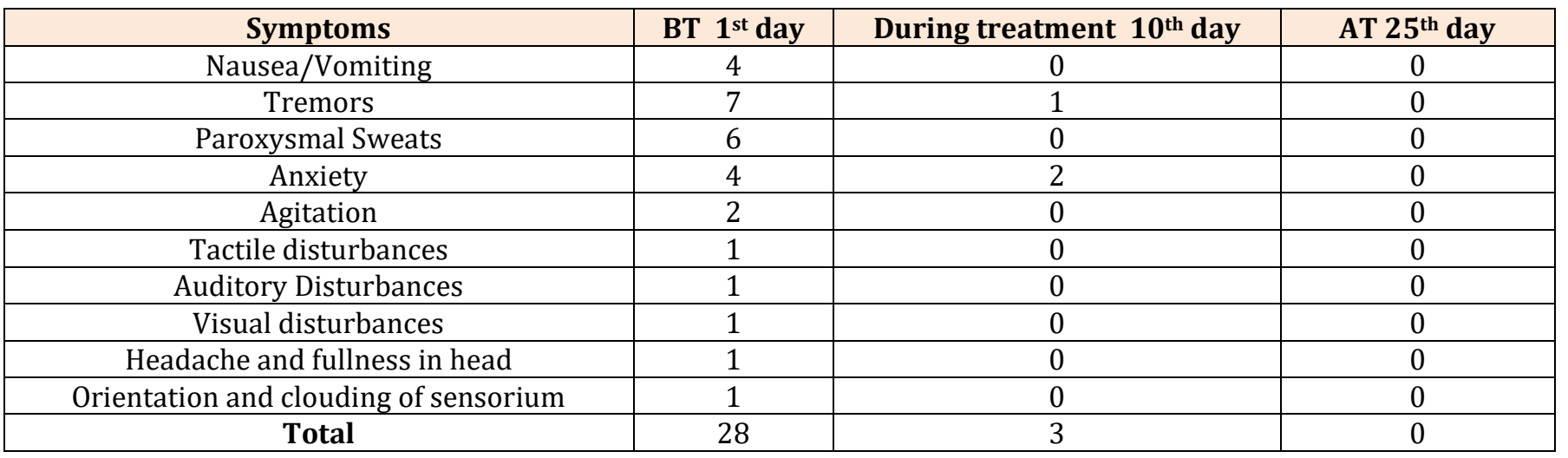

Table 5: Clinical Institute Withdrawal Assessment of Alcohol revised scale (CIWA-Ar scale). 


\section{Medical Journal of Clinical Trials \& Case Studies}

\section{Outcome of the Treatment}

On assessing the condition of patient after 25 days of treatment, by using the CIWA-Ar scale, it was observed that all the symptoms got reduced significantly after 10 days of the treatment. After 25 days, sleep was normal, appetite got increased and food intake became adequate, generalized fatigue was reduced. Almost all the symptoms subsided with the therapy. There was an overall improvement in functional capacity of the patient. He responded very much to our treatment and joined a new job later.

\section{Discussion}

The condition was approached and managed with the principles of management of madatyaya as already explained. The initial approach was Amapachana, Agnideepana and Srotorosodhana, which is ideal in madtyaya. On sudden abstinence of alcohol, agni which maintain the equilibrium of body gets altered, leading to to formation of ama. The ama causes srodhorodha and resulting deficit in bala. Hrdaya which is the cetana stana and sthana of functions of the mind also gets affected. The anulomana property of Vata gets deranged and affects the functions of body as well as mind. These processes occur straight away and manifest as symptoms of AWS.

Snehana, Swedana, Sodhana ie. either Vamana or Virechana, followed by vasthi, nasya, moordhni taila ending with rasayana is the algorithm of management for Madatyaya. Before performing sodhananga snehapana, rookshana is crucial, which subsides the associative Kapha or ama and causes anulomana to Vatha, also enhances the agni. For the same, Ajamoda arka was administered upto 7 days. As Ajamoda arka which is kaţurasa and vipaka and of ușnavirya helps to get rid of srotorodha. This drug is specially meant for kostha rogas so possess site specific action in this regard. As it is a Vata Kaphahara drug along with this Vatanulomana also works. Because of its dipana property it kindles agni. By this process, the channels in connection with the manovahasrotas will be clarified, leading to a pleasant mind.

Swedana karma was aimed for achieving vishyandana and vilayanao of doshas so as to bring them into koshta which is removed from the body by Virechana here, performed after 3 days of swedana [29]. Avipathy choorna was used here in this regard. Nasya and tala was followed by rasayana ie. Sankupushpi and yashti choorna use for 1 month. . Such a protocol seems safe as well as effective in the management of AWS.

\section{Conclusion}

Alcohol Withdrawal Syndrome and other disorders of alcohol abuse have been mentioned with details in the ancient texts of Ayurveda. Here a multidisciplinary approach including detoxification, management of associative conditions and rehabilitation are too adopted here. In severe presentations, sodhana chikitsa followed by rasayana is the best available option. There is need of further researches in this regard so as to enhance the available Ayurvedic management.

\section{References}

1. Niraj Ahuja (2011) A short book of psychiatry. $7^{\text {th }}$ (Edn.), New Delhi: Jaypee brother's medical publishers, pp: 174.

2. (2012) Astangahrudayam Cikitsastanam (P M GovindanVaidyar, trnas, malayalam). 15th reprint. Kodungalloor: Devee bookstall, pp: 200-201.7/5-9

3. (2012) Astangahrudayam Nidanastanam (P M GovindanVaidyar,trnas,malayalam). 15th reprint. Kodungalloor: Devee bookstall, pp: 119.6/1.

4. Sullivan TJ, Sykora K, Scheneiderman, Naranjo CA, Sellers EM (1989) Assessmemt of Alcohol withdrawal: The revised Clinical Institute Withdrawal Assessment for alcohol scale (CIWA-Ar). British Journal of Addiction 84(11): 1353-1357.

5. Mathiharan K, Amrit K Patnaik (2005) Modi's Medical Jurisprudence and Toxicology. 23rd (Edn.), New Delhi: LexisNexis Butterworths, pp: 307.

6. Wendy Moelker (2008) Positive and Negative Alcohol Use- web 4 healths (Internet).

7. Gronbaek M (2009) The positive and negative health effects of alcohol- and the public health implications. Journal of internal medicine 265(4): 407-420.

8. Substance use, abuse and dependence: definition and causes of substance disorders.

9. National institute on Alcohol Abuse and Alcoholism (2016) A comparison between DSM-IV and DSM- V.

10. Sadock, Benjamin James, Sadock, Virginia Alcott (2011) Kaplan and Sadock's Synopsis of Psychiatry. Behaviors sciences/ Clinical psychiatry. Lippincott: Williams \&wilkins, pp: 626. 


\section{Medical Journal of Clinical Trials \& Case Studies}

11. Marlatt GA (1979) Alcohol Use and Problem Drinking: A Cognitive behavioural analysis. New-York: academic press, pp: 319-355.

12. Bhishagvacaspati Durgadatta Sastri (2002) Sarngadhara Samhita (Tatvadipika Hinditika). Varanasi: Chaukhamba Vidyabhavan, pp: 39.

13. Vaidya Yaadavji Trikamji Acarya (2015) Caraka Samhita of Agnivesa (the Ayurveda Deepika Commentary by Cakrapanidatta). Varanasi: Chaukhamnba Surabharati Prakashan, pp: 583. $24 / 27$.

14. Vaidya Yaadavji Trikamji Acarya (2015) CarakaSamhita of Agnivesa (the Ayurveda Deepika Commentary by Cakrapanidatta). Varanasi: Chaukhamnba Surabharati Prakashan, pp: 57. 8/6163.

15. (2016) Astangahrudayam Nidanasthanam (PM GovindanVaidyar, Commen, Malayalam). Kodungalloor: Devi Bookstall, pp: 123. 6/14.

16. VaidyaYaadavji Trikamji Ācārya, Narayan Ram Ācārya (2014) Susruthasamhitha of Susrutha (Nibandhasangraha commentary). Varanasi: Chaukhambaorientalia, pp: 743. 47/17-21.

17. Vaidya Yaadavji Trikamji Acarya (2015) Caraka Samhita of Agnivesa (the Ayurveda Deepika Commentary by Cakrapanidatta). Varanasi: Chaukhamnba Surabharati Prakashan, pp: 587. 24/107.

18. Kanjiv Lochan Ashtanga Hrudaya of Vagbhata (2017) Nidanasthana, Ciktsasthana, and Kalpa-Sidhisthana. New Delhi: Chaukhamba Publications, pp: 257. 7/1.

19. Kanjiv Lochan. Ashtanga Hrudaya of Vagbhata (2017) Nidanasthana, Ciktsasthana, and Kalpa-Sidhisthana. New Delhi: Chaukhamba Publications, pp: 259. 7/10.
20. Tiwari PV (2010) KasyapaSamhita (KhilaSthanam). Varanasi: Chaukhamba Sanskrit Sansthan, pp: 239.16/4.

21. Alcohol withdrawal. Medline plus (internet).

22. Caetano R, Clark CL, Greenfield TK (1998) Prevalence, trends, and incidence of alcohol withdrawal symptoms: analysis of general population and clinical samples. Alcohol Health Res World 22(1): 73-79.

23. Sana E, Mostallino MC, Busonero F, Talani G, Tranquilli S, et al. (2003) Changes in GABA-A receptor gene expression associated with selective alterations in receptor function and pharmacology after ethanol withdrawal. J Neurosci 23(37): 11711-11724.

24. Soyka M, Horak M (2004) Outpatient alcohol detoxification: Implementation efficacy and outcome effectiveness of a model project. Eur Addict Res $10(4): 180-187$.

25. American Psychiatric Association (2013) Diagnostic and Statistical Manual of Mental Disorders DSM V. $5^{\text {th }}$ (Edn.), Arlington, VA: American psychiatry publication, pp: 499.

26. BV Subrahmanyam (2016) Parikh's Text book of medical Jurisprudence, Forensic medicine and toxicology. 7th (Edn.), New-Delhi: CBS publishers and distributers private ltd, pp: 607.

27. American Psychiatric Association (2013) Diagnostic and Statistical Manual of Mental Disorders DSM V. $5^{\text {th }}$ (Edn.), Arlington, VA: American psychiatry publication, pp: 500 .

28. Ashtangahridya, of Vagbhatta, by Kavirajatridev Gupta, Chaukhabhaprakashana, Varanasi (2007) Sootrastana 17/29.

29. Indradeva Tripathi. Arkaprakasa of Lankadhipati Ravana, pp: 38. 